\title{
Study on Environmental Art Design Education and Cultivation of Innovative Talents in Colleges and Universities in China
}

\author{
Lichun Zhou \\ Faculty of Arts \\ Hubei University \\ Wuhan, China \\ e-mail: zlc0101@163.com
}

\begin{abstract}
Since creation is the nature of design, environmental art design education and cultivation of innovative talents in colleges and universities should be guided by market demand, curriculum setting should attach importance to students' experience of life, design thinking training and inheritance and innovation of traditional culture.
\end{abstract}

Keywords-originality; thought; feature; traditional culture; education

\section{INTRODUCTION}

During the new age that witnesses a rapid development and fast change of the society, China has to face the globalization and informatization before it has completely accomplished the whole process of industrialization, almost all enterprises in China have realized the importance of design, while originality has also become one of the elements of design differentiation. When foreign enterprises occupy China's high-end market and even the global market depending on advanced design philosophy, "made in China" is nothing but a pronoun for low price, low end and low value added. China is the country that has the largest number of design education institutions around the world, and it is a country that has cultivated the largest number of designers in the world, but why can't we cultivate first-rate design masters with international influence? How should the major of art design in colleges and universities cultivate innovative talents, get rid of "made in China" and realize "designed in China" as soon as possible is a primary task for theoretical and practical workers of design education.

\section{DESIGN AND DESIGN ORIGINALITY COMES FROM LIFE AND TRADITIONAL CULTURE}

\section{A. The Nature of Design}

Creation is the nature of design and innovation is the soul of design competitiveness. The duty of environmental art design is to serve the public by designing pleasant, beautiful, ecological and comfortable environmental space. It is most closely related to human life, and it is able to change people's behavior and life style. Living in caves and on trees in the primitive society, traditional dwellings in countries all over the world and the garden art in ancient China all reflect people's wisdom in creating the living environment in different regions and in different times. As said by Professor Zhang Qiman from Tsinghua University, "Life is the nature of environmental art design and its main aim is to make life beautiful....." Therefore, environmental art design refers to creation activities carried out for life. With interior design in the environmental art design field as the example, judging from the current creative market, creative design to improve the living environment and quality of life is mainly reflected in aspects such as indoor furniture design, furnishing and accessory design, lamp design etc. Generally, the major of art design in colleges and universities will have relevant courses about interior design, the key teaching points of which will usually be placed in aspects like style of space, indoor function layout and separation, streamline design, selection of color and material, design drawing etc., and the more detailed design such as furniture, furnishing, lamp etc. will most commonly be presented in the form of diagrammatic drawing, or courses like furniture design, furnishing design will be opened up alone. Although this kind of teaching method is relatively close to the reality and seems to be more systematic, yet it greatly hinders the cultivation of students' creativity, students will easily develop a kind of dependence or walk into stylized "alleys" of learning, the innovation consciousness of "design for life" has gradually disappeared, most students concentrate on the "shape" while forget the "life". Therefore, teachers should fully mobilize students' enthusiasm, stimulate their consciousness of innovation, train their creative thinking, and repeatedly emphasize that original design should be reflected in the entire function layout, the detailed furnishing design and even switch sockets that can be seen everywhere indoor.

\section{B. Design Thinking is an Important Reflection of Design Capability}

A qualified designer should be equipped with capabilities in four aspects, namely design thinking, design methods, design skills and design attainment. As said by Sohrab Vossoughi, "Design is not equal to beautification. Instead, it 
is a process that requires creative thinking - the nonlinear and broad way of thinking that links seemingly uncorrelated things together. Designers are thinkers who know how to see the world in different angles so as to constantly make innovations visually." As far as the author is concerned, design thinking is the first aspect that reflects design capability. Thinking is an ability that everyone has in thinking about problems, but different from general ways of thinking, design thinking is mainly divided into logical thinking, thinking in terms of images and inspirational thinking. In the stage when design originality is being formed, design thinking determines whether a design can succeed or not. To form design thinking, designers need to have abundant knowledge reserve and information source so that when contacting the design and thinking about theme of the design, they can collect and extract relevant information in their broad and profound knowledge reserve so as to stimulate design inspiration and find the correct design thinking. Distinguish, extract and integrate all kinds of information using the logical thinking, create design elements and symbols with thinking in terms of images. Without the capability of design thinking, there will be no innovation. It would be difficult to create innovative works out of the ordinary even though you might have plenty of design methods and superb presentation skills. Design attainment knows no end, it not only reflects the idea and taste of innovative design, but it also runs through the whole process of design. The capability of design thinking also reflects a designer's attainment which is mainly accumulated step by step.

As a complicated comprehensive subject, environmental art design horizontally involves architecture, architectural structurology, sociology, folklore, human engineering, the science of law, art, design science, aesthetics, decorative materials science, fire fighting and environmental protection, furnishing etc., while longitudinally, it involves space design of human life and working places such as residence, office, business, cultural entertainment, public services and facilities and so on. Therefore, the innovation ability of environmental art designers is not simply determined by the accumulation of knowledge, instead, it depends on the width and breadth of their innovation ability, namely whether they have the ability to comprehensively apply multiple kinds of knowledge. Meanwhile, design originates from life and practice. Kenya Hara, a famous Japanese designer said in his book Designing Design, "Design is not only a skill, more importantly it is the sensory capacity and insight that captures the nature of things, and designers should be sensitive to the society all the time. Life is the origin of design, while design in the final analysis is the statement we make about life." Experiencing life is also the best way to cultivate design thinking and stimulate inspiration. Designers should constantly expand their vision, work hard to improve their ideological level and gain more life experience, because only in that way can they continuously expand their design thinking and design innovative works.

\section{Traditional Culture is the Foundation of Design Originality}

The development of human history always makes innovations during inheritance. Various design powers around the world in this contemporary era attach great importance to traditional culture. For example, though the United States does not have profound traditional culture, yet it attaches great importance to traditional cultures such as Indian culture, colonialist culture etc. In 1994, the United States formulated National Standards for Arts Education. Its stipulation about visual arts covers sketch, drawing, sculpture, design, architecture, film, television and folk art; it has confirmed the function of art education on students' allround development and the construction of a civilized society; it regards the historical, cultural and national background of art as the foundation of art courses, and emphasizes the cultural diversity of art education. For another example, on the 2010 Shanghai Expo, the design of everyone country without exception shows its unique national culture to the world: "The Little Mermaid" from Denmark, the "Gelle Fra Memorial" from Luxembourg, the Korean Pavilion constructed by characters etc. Every country brought traditional culture that fully reflects its national characteristics onto the stages on the Shanghai Expo. It is thus clear that there is no contradiction between traditional culture and modern culture, the former of which is the soul of Chinese design while the latter is the aim of Chinese design. The fundamental requirement of creative design with Chinese characteristics should be how to combine modern science and technology, carry forward traditional Chinese culture with positive values in form and spiritually so as to create design works that accord with modern aesthetic appreciation.

As you can see from courses set by the major of environmental art design in most colleges and universities in China, traditional culture education has been severely ignored, including the quintessence of Chinese culture such as the Book of Changes, Confucianism, Buddhism and Taoism etc., traditional folk handicraft, drawing, famous literary works and so on. Therefore, students' designs are usually piled up by traditional cultural symbols but lack inherent cultural deposits at a deeper level. Laozi, the founder of Taoism, said, "Motion and variation that move in circles is the movement of Taoism" which means that tradition endows us with new lives and there are no established rules and regulations for tradition and modern. Thus, the awareness of protecting traditional culture and respecting history should be constantly strengthened among students so as to make deeper cultural deposits naturally reflected during the design process.

\section{Design Education Strives to Cultivate INNOVATIVE TALENTS WITH CHINESE CHARACTERISTICS}

Design in contemporary China has always been working hard to transform from "made in China" to "designed in China", while the improvement of deign strength also lies in the improvement of the ideas, methods and environment of design education. 


\section{A. Transformation of Times on Design Education and Reform of the Design Education System}

If the education is thriving, then the nation will be prosperous and the country will be flourishing. In Chinese society, due to the influence of traditional Confucian culture and the imperial examination system that had lasted for over a thousand years, the concept of "To be a scholar is to be the top of society" is deep-rooted in people's heart, and the increase of people's economic income also provides powerful support for thriving entrance demand of higher education. Chinese higher education has transformed from the traditional elite education to mass education. Due to expansion of college enrollment, relatively promising career prospect and comparatively low entrance requirements, the number of design majors in colleges and universities is rising rapidly, the branches of design major are more detailed, the design major in most colleges and universities lacks clear features, students graduating from design major usually need to work for two or three years before they can adapt to the state of design work, and even abundant graduates abandon what they have learned for four years in college to work in other industries. Prof. Gerhard Mathias, a German who used to teach in many Chinese design colleges once said in his article, Majestic in Appearance: Current Chinese art design education has been cultivating "groups after groups of inferior-quality graduates trained from a defective assembly line of education." The outsider sees the most of the game. What Mathias said reflects realistic problems existing in China's current design education.

With a rather late start, China' $\mathrm{s}$ design education has experienced from the update and transformation from "arts and crafts education" to "design education", and artistic design was not a truly independent subject until the end of the 20th century. As maintained by Design Education written by Pan Lusheng, the development of China' s art and design education has experienced the stage dominated by pattern and craft, the stage dominated by craft and decoration, the stage dominated by decoration and design, and the stage dominated by design and originality. During the stage dominated by pattern and craft, the Bauhaus design education ideas from Germany were introduced into China. In that stage and within a very long period of time afterwards, almost all art colleges and comprehensive universities with design and art major in China were influenced by Bauhaus' design philosophy of "the unification of art and technology" and its design education mode of "factory apprentice system". Although Bauhaus' design educational system is not perfect and it is criticized by many people at present, yet it is undeniable that this system keeps up with the development of the times. When learning from outstanding educational ideas in foreign countries, China should think about its own characteristics and tradition instead of blindly copying, following or superficially imitating the outside form. For China, a country that is currently exploring the reform of design education system, "Bauhaus" is still a model that worth in-depth studying and researching.

\section{B. Cultivate Innovative Design Talents with Chinese Characteristics}

The aim of modern design education is to cultivate innovative design talents with modern art design consciousness, modern science and technology awareness and modern design thinking. Traditional design education system is based on the accumulation of knowledge and is skill-oriented, and students mainly accept knowledge in a passive way. As said by Mr. Yang Xianjiang, "Innovative talents are active, while utensils are passive", "innovative talents are able to utilize and create utensils while utensils can only be used and created by people." That is also one of the factors that have caused the "made in China" phenomenon. Under the background of establishing an innovation-oriented country, the design education system also remains to be reformed so as to adapt to the development of the cultural creative industry. Only by turning to the multidisciplinary and comprehensive development that combines originality and practicality can the design education system satisfy demand of the design market. How to cultivate innovative talents is a problem urgently needing to be solved by higher education. Modern psychology believes that "feature" refers to the spiritual outlook of a person or a community, it is the sum total of a person or a community' $s$ consciousness tendency and various kinds of stable but unique psychological features. To form "Chinese characteristics", China' s higher education must adhere to the spirit of being practical and realistic, the national spirit and the innovative spirit, that is, to cultivate innovative design talents with strong professional and humanistic quality based on China' $\mathrm{s}$ national conditions and the market demand. The market is constantly changing, students have to enter the market in the end to accept the fierce competition where the superior are selected while the inferior are eliminated, and design achievements have to be tested by the market ultimately. Therefore, the development direction of the major of art design in colleges and universities and the setting of its courses should be timely adjusted according to the market demand, meanwhile students should keep a watchful eye on the market trend all the time, participate in design competitions and design practical activities as much as possible, courses like marketing should be properly established so as to guide students to find their own advantages and learn how to sell themselves and their design works to the market.

The cultivation of national spirit is mainly reflected in the humanistic quality education dominated by traditional Chinese culture. The humanistic quality education mainly improves students' cultural taste, aesthetic taste, humanistic quality and scientific quality by strengthening education in humanistic and social science and natural science aspects such as literature, history, philosophy, aesthetics etc. By setting up courses about traditional Chinese culture such as design philosophy in ancient China, Yi-ology, Confucianism, Taoism, Buddhism, traditional opera and so on, outstanding traditional Chinese humanistic thought can be inherited so as to unconsciously influence students' design concept and improve their artistic attainment. In addition, craftsmanship in designing and making things in ancient China were 
exquisite, but few of them have been handed down up to now, some of them have no successors in China but are well carried forward in foreign countries. Therefore, the cultivation of national spirit also lies in the inheritance of traditional craftsmanship, making young people who accept modern design ideas become interested in traditional craftsmanship so as to make innovative use of it and carry forward it on the basis of inheritance.

The cultivation of national spirit is mainly reflected in the humanistic quality education dominated by traditional Chinese culture. The humanistic quality education mainly improves students' cultural taste, aesthetic taste, humanistic quality and scientific quality by strengthening education in humanistic and social science and natural science aspects such as literature, history, philosophy, aesthetics etc. By setting up courses about traditional Chinese culture such as design philosophy in ancient China, Yi-ology, Confucianism, Taoism, Buddhism, traditional opera and so on, outstanding traditional Chinese humanistic thought can be inherited so as to unconsciously influence students' design concept and improve their artistic attainment. In addition, craftsmanship in designing and making things in ancient China were exquisite, but few of them have been handed down up to now, some of them have no successors in China but are well carried forward in foreign countries. Therefore, the cultivation of national spirit also lies in the inheritance of traditional craftsmanship, making young people who accept modern design ideas become interested in traditional craftsmanship so as to make innovative use of it and carry forward it on the basis of inheritance.

\section{CONCLUSION}

As said by the German educator Spranger, "The aim of education is not to pass on knowledge that has already been there, instead it aims to induce people' $s$ creative power, awaken their sense of life and value." Design education is quality-oriented education as well as skill education. The purpose of design education is to achieve cognition about general problems by solving individual problems instead of teaching students the way and method to address one specific problem. In this individualized era where the information is constantly changing, only by adapting to the market demand and cultivating the national spirit can higher design education form "Chinese characteristics" so as to inherit and innovate the national culture and realize "designed in China".

\section{REFERENCES}

[1] Qin Jueying, History of Design Education in the 20th Century China. Zhejiang University Press, 2013.

[2] Pan Lusheng, Essays in Design and Art Education. Shandong pictorial publishing house, 2005.

[3] Kenya Hara, Designing Design. Guangxi Normal University Press, 2004.

[4] Hartley J., eta1. Creative Industry and Innovation in China [J]. International Journal ofCultural Studies, 2006(3)

[5] Gary D. Borich.Effective teaching Methods [M]. 4th Edition. Merrill New Jersey, Columbus, Ohio, 2000. 